Jurnal Pendidikan dan Pemberdayaan Masyarakat
Volume 3 - Nomor 1, Maret 2016, (1 - 15)

\title{
EVALUASI PROGRAM PELATIHAN PEMUDA DALAM MENINGKATKAN SDM DI HMI KOORDINATOR KOMISARIAT UNM
}

\author{
Andi Hasdiansyah ${ }^{1)}$, Yoyon Suryono ${ }^{2)}$ \\ ${ }^{1}$ Universitas Negeri Makassar, Jl. A.P. Pettarani Makassar 90222, Indonesia. \\ Email: ahasdiansyah@gmail.com \\ ${ }^{2}$ Pendidikan Luar Sekolah, Universitas Negeri Yogyakarta, Jl. Colombo No. 1, Karangmalang \\ Yogyakarta 55281, Indonesia. Email: yoyonsuryono@yahoo.com
}

\begin{abstract}
Abstrak
Penelitian ini bertujuan untuk mengetahui: (1) dampak program basic training pemuda di HMI cabang Makassar, (2) tujuan program basic training pemuda, (3) keluaran dari program basic training pemuda, (4) aktivitas program basic training pemuda, (5) masukan basic training pemuda, (6) hambatan program basic training pemuda, dan (7) merekomendasikan pengem-bangan model program pelatihan dasar pemuda di HMI cabang Makassar. Penelitian evaluasi ini merujuk pada konsep Logical Framework Models dan dianalisis secara kualitatif. Subjek penelitian 9 alumni pelatihan. Data penelitian ini dikumpulkan melalui wawancara mendalam, observasi tidak langsung, dan analisis dokumen. Hasil penelitian ini menunjukkan 7 temuan. Pertama, pelatihan berdampak positif karena tercipta perubahan yang diinginkan meskipun belum sepenuhnya. Kedua, tujuan pelatihan tercapai meskipun belum sepenuhnya. Ketiga, kompetensi keluaran pelatihan meningkat tetapi belum mampu bertahan dalam jangka waktu yang lama. Keempat, aktivitas pelatihan sudah memenuhi kriteria pembelajaran; akan tetapi, keberhasilan tersebut hanya berakhir di dalam forum pengkaderan. Kelima, masukan pelatihan dikategorikan baik tetapi belum sepenuhnya mengikuti pedoman pengkaderan. Keenam, hambatan pelatihan adalah biaya dan kurangnya kedisiplinan pemateri dengan peserta pelatihan. Ketujuh, memantapkan kajian keislaman, meminimalisir kelemahan administrasi, dan memperketat proses perekrutan.
\end{abstract}

Kata Kunci: evaluasi, pelatihan pemuda, basic training, HMI, logical framework models

\section{THE EVALUATION OF YOUTH TRAINING PROGRAM TO IMPROVE HR IN HMI COORDINATOR COMMISARIAT UNM}

\begin{abstract}
This study aims to determine: (1) impact of youth basic training program in HMI Makassar branch, (2) purpose of youth basic training program, (3) output of youth basic training program, (4) activity of youth basic training program, (5) input of youth basic training program, (6) barriers of youth basic training program, and (7) recommending the development model of the youth basic training program in HMI Makassar branch. The evaluation study refers to the concept of logical framework models and analyzed qualitatively. Subjects of study were nine people who are alumni of training. Data research were collected through interviews, observation indirectly, and documents analysis. The result of study showed seven findings. First, training has a positive impact since created the desired changes though not yet fully. Second, training objective was achieved, although not completely. Third, competence of output training increased, but have not been able to survive in the long term. Fourth, activity training meets the criteria of learning; however, success of forum just ended in the cadre. Fifth, inputs training are considered as good, but not fully follow the cadre guidelines. Sixth, the barriers training are cost and lack on discipline presenters and participants. Seventh, establishing Islamic studies, minimizing administrative weaknesses, and tightening recruitment process.
\end{abstract}

Keywords: evaluation, youth training, basic program, HMI, logical framework models

How to Cite: Hasdiansyah, A., \& Suryono, Y. (2016). Evaluasi program pelatihan pemuda dalam meningkatkan SDM di HMI koordinator komisariat UNM. Jurnal Pendidikan dan Pemberdayaan Masyarakat, 3(1), 1-15. Retrieved from http://journal.uny.ac.id/index.php/jppm/article/view/8o62 


\section{Jurnal Pendidikan dan Pemberdayaan Masyarakat, 3 (1), Maret 2016 - 2}

Andi Hasdiansyah, Yoyon Suryono

\section{PENDAHULUAN}

Indonesia merupakan negara berdaulat yang telah mendapat pengakuan dunia. Negara yang telah mendapatkan pengakuan mensyaratkan adanya keberadaan pemerintahan, wilayah, dan warga negara. Ketiga elemen ini merupakan unsur utama dalam menopang keberlangsungan satu negara. Salah satu elemen yang memiliki peranan penting adalah warga negara atau penduduk. Jika dipilah, bagian dari warga negara Indonesia dapat digolongkan pada dua arus besar yakni kaum muda dan kaum tua.

Kedua elemen tersebut, kaum muda sering ditafsirkan sebagai pemuda yang memiliki pengaruh besar pada kemajuan suatu negara. Indonesia dalam sejarahnya telah menunjukkan bahwa proklamasi kemerdekaan Indonesia diinisiasi oleh pemuda. Hal tersebut bisa dilihat melalui keterlibatan pemuda dalam perjuangan kemerdekaan negara Indonesia yang tidak bisa dipungkiri telah membawa angin segar bagi rakyat Indonesia. Kehadiran pemuda adalah bukti bahwa semangat juang pemuda pada saat itu sangat tinggi, nasionalisme sangat kuat dan secara radikal menolak penjajahan. Kiprah pemuda bisa dilihat dari gerakan mereka sejak sebelum momentum kebangkitan nasional hingga pasca reformasi saat ini.

Bukan hanya itu, berbagai hal juga menjadi pemicu bangkitnya gerakan yang dipelopori oleh kelompok pemuda dan mahasiswa. Syam (2010, p.3) antara lain adalah naiknya harga barang-barang pokok dan ketidakpuasan masyarakat atas kondisi sosial politik yang sangat mengekang dan memasung kebebasan. Asumsi tersebut menjadi dasar perjuangan pemuda, mahasiswa, serta berbagai komponen bangsa untuk menyuarakan kebenaran. Saat itu, gerakan sosial adalah satu-satunya solusi yang harus dilaksanakan. Hal tersebut senada dengan pendapat Takashi Shiraisi (Syam, 2010, p.4) bahwa gerakan sosial sebagai alat ekspresi politik rakyat untuk menyampaikan hal yang benarbenar disampaikan kepada Negara.

Sekarang, menurut BPS tahun 2013 Indonesia akan mengalami pertumbuhan penduduk yang signifikan yaitu dari 238,5 juta pada tahun 2010 menjadi 305,6 juta pada tahun 2035. Oleh karena itu, harus generasi produktif yang akan lahir harus dimanfaatkan. Saat ini, ini generasi muda harus mempersiapkan diri agar mampu bersaing meraih kesempatan kerja, dan bersaing dengan negara-negara lain di seluruh dunia. Artinya, mulai sekarang anak-anak harus mempersiapkan diri dalam mengembangkan kecerdasan intelektual, kecerdasan emosional, dan kecerdasan spiritual secara optimal. Upaya ini adalah tugas utama dari seluruh lembaga pemerintah maupun non-pemerintah di Indonesia untuk mengembangkan potensi yang dimiliki oleh pemuda.

Pengembangan itu dapat dilakukan pemerintah dan masyarakat melalui pendidikan sekolah maupun pendidikan luar sekolah. Pendidikan sekolah dan pendidikan luar sekolah merupakan satu kesatuan integral yang tidak dapat dipisahkan dari sistem pendidikan nasional. Pendidikan nasional yang dicita-citakan pancasila bertujuan untuk meningkatkan ketakwaan kepada Tuhan yang maha esa, menumbuhkan kecerdasan, mempertinggi budi pekerti, memperkuat kepribadian, dan mempertebal semangat kebangsaan agar dapat membangun dirinya sendiri serta bersama-sama bertanggung jawab atas pembangunan nasional. Pendidikan pada hakikatnya dilaksanakan sepanjang hayat yang mencakup segala aspek, proses dan siklus kehidupan manusia sejak dalam kandungan, hingga usia lanjut atau sampai ke liang lahat. Pendidikan sekolah dan pendidikan luar sekolah merupakan tanggung jawab pemerintah, masyarakat dan keluarga. Oleh sebab itu, peran aktif semua pihak dalam jenis dan jenjang pendidikan diselenggarakan secara terpadu dan diarahkan pada peningkatan kualitas. Pendidikan luar sekolah tidak hanya diselenggrakan oleh pemerintah namun semua aspek elemen-elemen yang ada termasuk elemen pemuda.

Pendidikan nonformal menurut Axin (Suprijanto 2008, p.7) adalah kegiatan belajar yang disengaja oleh warga belajar dan pembelajar di dalam suatu latar yang diorganisasi (terstruktur) yang terjadi di luar sistem persekolahan. Selain itu, pendidikan nonformal menurut Komar (2006, p.213) adalah pendidikan yang diselenggarakan di luar sekolah, baik dilembagakan maupun 
tidak dan dilakukan secara terbuka, tidak terikat, dan tidak terpusat. Pendidikan nonformal mempunya medan yang sangat luas daripada pendidikan formal yang kemudian dalam pelaksanaannya dapat disesuaikan dengan kebutuhan masyarakat yang senantiasa berubah-ubah.

Berangkat dari pengertian tersebut, dapat dirumuskan bahwa lembaga-lembaga yang dibentuk oleh masyarakat dan program pendidikan yang secara sengaja dan terstruktur merupakan agenda pendidikan luar sekolah, termasuk lembaga kepemudaan yang melaksanakan program pelatihan. Tentu hal tersebut dilakukan dalam rangka mengembangkan sumber daya manusia. Tilaar (Djuwariah, 2008, p.16) menyebutkan unsurunsur ketahanan suatu bangsa menjadi tiga yaitu sumber daya alamnya, sumber daya manusianya yang berkualitas, dan sumber daya kebudayaan dan kesejarahannya. Oleh sebab itu, sumber daya manusia yang berkualitas tentunya menjadi tugas utama pendidikan. Apalagi sumber daya manusia yang dimaksud adalah pemuda atau biasa disebut sekelompok manusia yang memiliki potensi dan kelompok yang penuh vitalitas, semangat patriotis (Mappiare, 1982, p.12). Selain itu, pemuda atau generasi muda adalah konsep-konsep yang sering diberati atau dibebani oleh nilai-nilai dalam masyarakat. Hal tersebut disebabkan karena keduanya bukanlah semata-mata istilah ilmiah, tetapi sering lebih merupakan pengertian ideologis atau kultural yang tercermin dalam istilah pemuda harapan bangsa, pemuda pemilik masa depan, dan pemuda penerus bangsa, Abdullah (Wijaya, 2013, p.77). Pengertian lain pemuda/remaja menurut Erikson (Kartono, 1992) dianggap ada dalam satu periode transisi dengan tingkah laku antisosial, disertai dengan banyak pergolakan hati atau kekisruhan batin pada fase-fase remaja (Tristanti \& Suryono, 2014).

Berangkat dari pengertian pemuda di atas, tentu membutuhkan tafsiran tentang bagaimana cara atau strategi pengembangan sumber daya pemuda. Moerdiyanto, (2011, p.1) menguraikan pandangannya tentang strategi pembangunan pemuda yang dapat dilakukan dengan cara (1) membangun moral dan budi pekerti luhur dan suci, (2) membangun sarana prasarana fisik dan nonfisik dengan mengedepankan kepentingan bangsa dan negara tersebut kepentingan pribadi, kelompok atau golongan, (3) membangun sumber daya manusia dengan keteladanan, solidaritas, gotong royong, sopan santun, ramah tamah, saling menghormati, dan saling menghargai, dan memelihara kepekaan social, (4) membangun semangat juang dan cinta tanah air, dan (5) membangun future mapping sebagai blue print for nation character building.

Lebih dari itu, uraian tersebut dipertegas oleh pendapat Lerner (2010) (Bower, Li, Kiely, Brittian, Lerner, \& Lerner, 2010, p.721) bahwa untuk mengembangan pemuda tentu pihak terkait atau organisasi perlu memperhatikan 5 aspek berikut, (1) aspek kompetensi yang meliputi (kompetensi sosial, kompetensi kognitif, kompetensi akademik, dan kompetensi kejuruan). Kompetensi sosial berkaitan dengan keterampilan intrapersonal misalnya (resolusi konflik). Kompetensi kognitif berkaitan dengan kemampuan kognitif misalnya (pengambilan keputusan). Kompetensi akademik berkaitan dengan nilai ujian. Kompetensi kejuruan berkaitan dengan kebiasaan kerja, kewirausahaan dan eksplorasi karir. (2) aspek keyakinan berkaitan dengan rasa internal atau harga diri seseorang. (3) aspek koneksi berkaitan dengan hubungan pemuda dengan orang-orang di sekitarnya, seperti kerabat, keluarga, dan masyarakat umum. (4) aspek karakter berkaitan dengan rasa hormat kepada atauran dan norma sosial yang berlaku, moralitas, dan integritas. (5) aspek merawat berkaitan dengan rasa simpati dan empati terhadap orang lain.

Mengacu pada beberapa pendapat tokoh tersebut maka sekiranya dibutuhkan wadah alternatif. Wadah tersebut adalah pelatihan. Goldstein \& Ford (2002, p.1) menjelaskan bahwa, "training is defined as the systematic acquisition of skills, rules, concept, or attitudes thet result in improved performance in another environment". Ditambahkan juga oleh Fauzi (2011, p.7) bahwa pelatihan adalah sebuah kegiatan yang sengaja dirancang untuk mentransfer ilmu pengetahuan dan keterampilan kepada seseorang atau kelompok dalam upaya mening- 


\section{Jurnal Pendidikan dan Pemberdayaan Masyarakat, 3 (1), Maret 2016 - 4}

Andi Hasdiansyah, Yoyon Suryono

katkan kapasitas dirinya di tempat kerja atau tempatnya beraktivitas.

Pendapat beberapa ahli tersebut menguatkan bahwa pelatihan menjadi hal yang sangat penting dalam mengembangkan sumber daya manusia olehnya itu membutuhkan manajemen yang baik. Sudjana (2008, p.2) mengartikan manajemen adalah kegiatan untuk mendayagunakan sumber daya manusia, sarana dan prasarana serta berbagai potensi yang tersedia atau yang dapat disediakan untuk digunakan secara efisisen dan efektif dalam mencapai suatu tujuan organisasi atau lembaga. Manajemen juga berfungsi merencanakan, mengorganisasikan, memerintahkan, mengkoordinasikan dan mengendalikan, namun dewasa ini kita memadatkan lima fungsi-fungsi manajemen suatu kegiatan tersebut menjadi empat: perencanaan, pengorganisasian, kepemimpinan, dan pengendalaian (Robbins, 2008, p.4). Lebih lanjut, Mujiman (2009) memberikan batasan manajemen pelatihan menyangkut aspek pengidentifikasian kebutuhan pelatihan, perencanaan desain pelatihan, penetapan metodologi pelatihan, menyusun bahan pelatihan, pelaksanaan pelatihan, evaluasi pelatihan, dan tindak lanjut pelatihan.

Terkait dengan pelatihan, sejak tahun berdirinya HMI cabang Makassar tidak pernah berhenti melakukan gerakan kepemudaan dalam rangka mengembangkan kualitas pemuda salah satunya melalui program basic training. Sehingga berdasarkan pada data HMI cabang Makassar, pemuda yang telah mengikuti basic training dari tahun 20062013 sebanyak 14.00o kader. Pemuda yang dimaksud adalah mahasiswa yang masih aktif atau terdaftar disebuah perguruan tinggi. Hal tersebut membuktikan bahwa semangat belajar pemuda Makassar cukup tinggi. Oleh karena itu, peran pemerintah dan masyarakat sangat diperlukan dalam rangka pengembangan kualitas sumber daya pemuda yang berdaya saing global.

Sekian banyak jumlah kader yang dicetak oleh HMI cabang Makassar tentu menjadi menarik untuk diteliti. Program basic training tersebut menarik minat pemuda untuk mengikutinya. Oleh karena itu, untuk mengetahui sejauh mana keberhasilan atau pencapain tujuan basic training HMI cabang Makassar diperlukan penelitian evaluatif. Sitiatava (2013, p.15) memberikan pemaknaan bahwa evaluasi merupakan suatu proses, dimana informasi dan pertimbangan diolah untuk membuat suatu kebijaksanaan yang akan datang. Lebih lanjut, Jorjani, et.al (1994, p.74) mengemukakan pendapatnya tentang evaluasi dalam arti yang luas bahwa:

In a broad sense, evaluation is a systematic process of expert enquiry to evaluate the performance and effectiveness of various activities within an organization. In other words, evaluation is a "feedback" process through which information is generated. This information is considered an important management tool that decision-makers can use to continually improve the operation of the organization.

Disisi lain, Sylvia N \& Wilfred U (2012, p.3) mengungkapkan betapa pentingnya evaluasi "if training and development is a process of updating knowledge, skills and abilities of employees to improve their job performance, then training and development should be evaluated". Pengertian yang dikemukakan oleh tokoh tersebut menegaskan bahwa evaluasi merupakan sebuah proses penting yang harus ada dalam pelaksanaan suatu program. Ditegaskan pula oleh Weiss \& Henry (Fitzpatrick, Sanders \& Worthen, 2011, p.13) berpendapat bahwa"the purpose of evaluation is to bring about social betterment.".

Beberapa pengertian, tujuan, dan fungsi evaluasi tersebut mengarahkan peneliti untuk mengkaji lebih dalam program basic training HMI cabang Makassar. Penelitian evaluasi ini bertujuan untuk mengetahui (1) dampak program basic training HMI cabang Makassar bagi pemuda. (2) tujuan program basic training HMI cabang Makassar bagi pemuda.(3) keluaran program basic training HMI cabang Makassar bagi pemuda. (4) aktivitas program basic training HMI cabang Makassar bagi pemuda. (5) masukan program basic training HMI cabang Makassar bagi pemuda. (6) hambatan program basic training HMI Cabang Makassar bagi pemuda, dan (7) merekomendasikan pengembangan model program basic training HMI Cabang Makassar bagi pemuda. 


\section{Jurnal Pendidikan dan Pemberdayaan Masyarakat, 3 (1), Maret 2016 - 5}

Andi Hasdiansyah, Yoyon Suryono

\section{METODE}

Penelitian ini merupakan penelitian evaluasi dengan pendekatan kualitatif. Penelitian ini dilaksanakan di HMI cabang Makassar dan difokuskan pada 9 komisariat yang ada di Universitas Negeri Makassar. Waktu penelitian dilaksanakan pada bulan februari sampai pada bulan april 2015. Teknik pengumpulan data yang digunakan adalah wawancara, observasi, dan dokumentasi dengan model analisis pengumpulan data, pengkodean, penyajian data, dan penarikan kesimpulan. Teknik keabsahan data menggunakan triangulasi sumber.

\section{HASIL DAN PEMBAHASAN}

\section{Hasil Penelitian}

Berdasarkan hasil wawancara, observasi, dan dokumentasi dengan alumni basic training HMI cabang Makassar. Maka dapat dikatakan bahwa program basic training HMI cabang Makassar berdampak pada peningkatan kemampuan akademik alumni. Hal tersebut dapat dilihat dari Indeks Prestasi Kumulatif (IPK) alumni tidak menurun setelah mengikuti pelatihan, hampir semua informan memiliki IPK di atas 3.00. Alumni basic training mampu menciptakan situasi menjadi lebih baik ketika terjadi sesuatu di kampus maupun di lingkungannya. Disisi lain alumni memiliki jiwa pengabdian yang tinggi dan selalu bertanggungjawab atas terwujudnya masyarakat adil makmur yang diridhoi Allah SWT. Akan tetapi, untuk aspek keislaman, alumni dinilai belum mampu menjalankan ajaran agama Islam dengan baik.

Tujuan basic training terdiri atas 4 target yang harus dicapai. Target yang telah dicapai adalah alumni mampu meningkatkan kemampuan akademisnya, alumni memiliki kesadaran berorganisai dan memiliki tanggungjawab keummatan dan kebangsaan yang tinggi. Akan tetapi, disisi lain alumni belum mampu menjalankan ajaran agama Islam dengan baik.

Keluaran basic training HMI cabang Makassar bervariasi. Kompetensi yang dimiliki dalam hal ini adalah penguasaan materi dasar pengaderan. Pada materi sejarah dan dinamika HMI, alumni telah mampu menja- barkannya secara umum, untuk materi konstitusi HMI dari 9 informan hanya 1 orang yang benar mengerti dan memahami materi tersebut, alumni yang lain hanya bisa menjelaskan tujuan dan fungsi konstitusi dalam sebuah organisasi tetapi tidak mampu menjelaskan jika organisasi tersebut adalah HMI. Materi mission secret HMI rata-rata dipahami oleh alumni basic training. Untuk materi nilai dasar perjuangan masih terdapat beberapa alumni yang belum memahaminya secara khaffah. Sedangka untuk materi keorganisasian rata-rata dipahami oleh alumni basic training HMI cabang Makassar komisariat Universitas Negeri Makassar.

Aktivitas basic training atau proses pembelajarannya banyak menggunakan metode ceramah dan diskusi. Suasana yang terbangun di dalam forum pengaderan pun sangat menimbulkan gairah belajar peserta pelatihan. Selain itu, tercipta pula suasana yang equal jadi peserta merasakan kenyamanan saat mendengarkan materi maupun menyampaikan pendapatnya. Untuk sarana dan prasarana, tersedia dengan baik begitupun dengan anggaran kegiatan dan kualifikasi fasilitator sesuai standar yang telah ditentukan oleh HMI cabang Makassar.

Masukan basic training terdiri atas sumber dana, peserta, sarana dan prasarana. Sumber dana basic training HMI cabang Makassar berasal dari para senior HMI dan usaha kreatif penyelenggara kegiatan. Peserta basic training yang menjadi informan penelitian adalah mahasiswa dari kampus Universitas Negeri Makassar yang terdiri atas 9 komisariat di bawah naungan HMI cabang Makassar. Selanjutnya, sarana dan prasarana disediakan dengan baik oleh penyelenggara pelatihan sebelum basic training dilaksanakan.

Hambatan basic training HMI cabang Makassar khususnya yang diselenggarakan oleh 9 komisariat di Universitas Negeri Makassar adalah persoalan biaya dan kedisiplinan pemateri dan peserta pelatihan.

\section{Pembahasan}

Pengkaderan HMI cabang Makassar merupakan salah satu agenda perjuangan HMI dalam menyebarluaskan dan memahamkan kepada pemuda tentang kebenaran 
dan nilai-nilai keislaman yang sebaik-baiknya. Selain itu, membentuk karakter pemuda yang tangguh secara idealisme dan berintegritas dalam upaya pembangunan bangsa Indonesia yang lebih baik.

Pengkaderan atau basic training HMI cabang Makassar adalah pelatihan paling dasar yang wajib dilalui oleh mahasiswa untuk masuk menjadi anggota HMI. Pengkaderan dasar tersebut bermaksud membentuk sikap dan pengetahuan mahasiswa agar mampu menafsir dan mengelola kehidupan di masa kini dan masa yang akan datang. Sikap yang baik dan pengetahuan yang cukup, bagi HMI adalah modal besar dalam menjalani kehidupan. Oleh karena itu, pelatihan dasar yang diselenggarakan oleh HMI cabang Makassar membutuhkan manajemen pengelolaan yang baik serta narasumber dengan kualitas yang tidak diragukan.

Program basic training adalah tumpuan fundamental HMI cabang Makassar dalam mempertegas dirinya sebagai salah satu organisasi mahasiswa terbesar di Makassar. Oleh sebab itu, berbagai upaya dilakukan untuk memantapkan kemasan program tersebut. Tidak lain dan tidak bukan adalah untuk mengejawantahkan tujuan HMI khususnya di Makassar. Akan tetapi di dalam pergolakannya menuju mimpi tersebut HMI cabang Makassar mengalami berbagai rintangan dan kelemahan yang setiap saat harus dibenahi bersama-sama.

Terkait basic training HMI cabang Makassar yang difokuskan pada 9 komisariat di Universitas Negeri Makassar, terdapat banyak hal yang harus diuraikan secara detail, terutama dalam aspek manajemen pengelolaan training yang meliputi dampak program basic training, tujuan program basic training, keluaran program basic training, aktivitas program basic training, dan masukan program basic training.. Evaluasi program tersebut akan ditinjau dalam perspektif logis/ pendekatan hirarki logika yaitu keterkaitan antara dampak program pelatihan, pencapaian tujuan, keluaran, aktivitas, dan masukan. Menurut International Federation Of Red Cross and Red Crescent Societies (2002, p.6) Evaluation is the systematic and objective assessment of an on-going or completed operation, programme or policy, its design, implementation and results. The aim is to determine the relevance and fulfillment of objectives, as well as efficiency, effectiveness, Impact (overall Goal) and sustainability (evaluasi adalah penilaian yang sistematis dan objektif dari yang sedang berjalan atau operasi yang sudah selesai, program atau kebijakan, desain, implementasi dan hasil). Kelima komponen tersebut terkait dan saling menentukan. Dampak yang baik ditentukan oleh pencapaian tujuan yang baik pula, begitupun dengan keluaran ditentukan oleh aktivitas program yang bermakna, sejalan dengan hal tersebut aktivitas program yang bermakna tentu tidak lepas dari masukan yang baik pula terutama kualitas narasumber, ketersediaan sarana prasarana, dan keseriusan peserta pelatihan.

\section{Dampak Program Basic Training}

Dampak basic training HMI cabang Makassar yang diharapkan adalah peserta atau alumni pelatihan mampu mengaplikasikan 5 kualitas insan cita HMI. Adapun 5 kualitas insan cita yang dimiliki oleh kader HMI adalah sebagai berikut: Pertama kualitas insan akademis adalah kemampuan seorang kader mentransformasikan ilmu pengetahuan atau disiplin ilmu yang dimilikinya ke masyarakat dan mampu bekerja secara teratur dalam kehidupan sehari-hari. Pada konteks itu, kader HMI cabang Makassar dinggap memiliki kualitas akademik yang baik. Selain itu, kader memiliki keemampuan melaksanakan sesuatu sesuai dengan apa yang diketahuinya.

Kedua kualitas insan pencipta adalah kemampuan seorang kader HMI dalam menciptakan sesuatu atau karya-karya tertentu yang selalu berpedoman pada nilai-nilai keislaman, selain itu kader diharapkan mampu menciptakan kebaikan, bersifat terbuka, dan independen dalam kehidupan sehari. Kualitas tersebut secara garis besar belum dimiliki oleh kader HMI cabang Makassar dibuktikan dengan pengakuan kader atas beberapa perilaku buruk yang masih biasa dilakukan.

Ketiga kualitas insan pengabdi adalah kemampuan yang dimiliki oleh seorang individu dalam mengabdikan dirinya untuk masyarakat, bangsa dan negara. Hasil pembaca- 


\section{Jurnal Pendidikan dan Pemberdayaan Masyarakat, 3 (1), Maret 2016 - 7}

Andi Hasdiansyah, Yoyon Suryono

an di lapangan dan wawancara dengan informan penelitian menunjukkan hal yang positif. Kader HMI memiliki jiwa pengabdian yang baik dan membanggakan. Pengabdian dituangkan dalam berbagai kegiatan, baik bersifat individu maupun kolektif (HMI) misalnya, bakti sosial, pendampingan kasuskasus penggusuran, pendampingan kebijakan pemerintah, dan terlibat dalam pembangunan paradigma mahasiswa di kampus-kampus yang ada di Makassar.

Keempat kualitas insan bernafaskan islam adalah kemampuan individu dalam menjalankan nilai-nilai ke-islaman atau keagamaan. Konteks tersebut masih sangat menunjukkan berbagai kelemahan yang ditampakkan oleh kader-kader HMI melalui kebiasaan setiap hari misalnya, meninggalkan shalat 5 waktu, menyentuh barangbarang haram, dan anehnya lagi kebiasaan tersebut sudah menjadi rahasia umum dikalangan internal HMI cabang Makassar.

Kelima, kualitas insan yang bertanggung jawab atas terwujudnya masyarakat adil makmur yang diridhoi Allah SWT. Pada konteks ini, kader HMI telah mampu mempertanggungjawabkan perbuatan secara baik dan benar serta sesuai dengan norma dan nilai yang berlaku dilingkungan masyarakat. Selain itu, spontan menghadapi tugas organisasi dan jauh dari sikap apatis terhadap persoalan-persoalan yang dihadapi di masyarakat. Dari 5 aspek tersebut, merupakan sebuah pencapaian dalam kegiatan pengaderan yang dilakukan oleh HMI cabang Makassar, meski demikian masih terdapat kekurangan maupun kelemahan di dalamnya. Beberapa kekurangan yang dimiliki oleh kader HMI cabang Makassar, seperti meninggalkan shalat 5 waktu dan menyentuh barang haram. Akan tetapi, program pelatihan tersebut telah memberi makna seperti halnya ungkapan Zubaeri (Nuralam \& Sahide, 2011, p.17) bahwa makna pengkaderan HMI adalah menyadarkan kadernya agar mampu menjadi dirinya sendiri (capacity building) yang memadai sebagai bekal hidup dan fungsi kekhalifaan di muka bumi, yaitu penjaga keseimbangan antara mikrokosmos dengan makrokosmos hingga terciptanya dinamisasi hubungan yang saling membutuhkan tetapi tidak saling menguasai.
Temuan tersebut mengindikasikan bahwa basic training HMI cabang Makassar telah memberikan dampak positif meskipun belum bersifat komprehensif. Terdapat perubahan dalam diri seorang meskipun masih jauh dari harapan pelatihan dasar HMI cabang Makassar. Selain itu, terdapat perubahan yang tidak dinginkan yaitu perkembangan kualitas diri seorang kader tidak dibarengi dengan nafas perjuangan islam sehingga makna keberislaman tidak tampak dalam kehidupan sehari-harinya. Poros perjuangan itulah yang sebaiknya HMI cabang Makassar mantapkan lagi.

Perubahan individual yang terjadi dalam diri alumni pelatihan tidak bisa dipungkiri banyak dipengaruhi oleh basic training HMI cabang Makassar. Seperti yang diungkapkan oleh Goldstein \& Ford (2002, p.1) bahwa pelatihan memang sebagai wadah untuk meng-upgrade kemampuan secara sistematis, aturan, dan sikap yang menghasilkan peningkatan kerja di dalam lingkungan lain. Pelatihan dasar (basic training) HMI cabang Makassar telah memberikan hal tersebut kepada pemuda atau mahasiswa yang telah mengikuti kegiatan tersebut meskipun belum sepenuhnya berubah dalam semua aspek.

Setelah dievaluasi, dampak program pelatihan dasar mahasiswa oleh HMI cabang Makassar masih pada wilayah teoritik. Pelatihan secara umum belum mampu mendorong kemampuan praktis mahasiswa. Ditemukan, hanya beberapa diantara mahasiswa alumni pelatihan dasar HMI cabang Makassar mampu memadukan keduanya.

\section{Tujuan Program Basic Training}

Pencapaian tujuan basic training HMI cabang Makassar pada konteks keagamaan/ keislaman masih sangat kurang dan belum tercapai secara utuh. Kader atau informan dalam penelitian ini belum mampu menjalankan ajaran agama islam secara baik dan teratur. Setiap kader masih sering meninggalkan kewajibannya sebagai umat muslim, terlebih lagi banyak terlibat dalam kegiatankegiatan yang sesungguhnya dilarang oleh agama. Kebiasaan tersebut dipengaruhi oleh lingkungan yang sudah lama terbangun di HMI cabang Makassar. Akhirnya, anggota 


\section{Jurnal Pendidikan dan Pemberdayaan Masyarakat, 3 (1), Maret 2016 - 8}

Andi Hasdiansyah, Yoyon Suryono

baru turut meneladani kebiasaan pendahulunya. Sesungguhnya hal tersebut tidak boleh terjadi dalam organisasi yang menjadikan islam sebagai pedoman utama. Dari fenomena yang terjadi maka dapat dirumuskan bahwa keberislaman kader HMI belum sepenuhnya utuh.

Pada sisi lain, kegiatan organisasi alumni pelatihan tidak mengganggu aktivitas perkualiahan seorang kader. Rata-rata kader sanggup menyeimbangkan antara kegiatan organisasi dan rutinitas perkuliahan. Dapat dilihat dari peningkatan Indeks Prestasi Akademik (IPK) yang diraih dalam setiap semester di kampus masing-masing. Tidak kurang dari itu, informan penelitian menjadi lebih paham fungsinya sebagai pemuda yang dewasa dimana dalam konteks keluarga para informan penelitian banyak berperan membantu masalah orang tua ataupun saudaranya dirumah. Apalagi setiap informan berasal dari daerah yang jauh dari kota sehingga akses informasi sangat kurang. Disitulah letak peran mahasiswa atau kader HMI dalam urusan keluarganya masingmasing.

Selain itu, pada sisi sosial kemanusiaan kader HMI layak diberi penghargaan. Keterlibatan para kader dalam kegiatan-kegiatan sosial dan kemanusiaan telah memberi kontribusi positif dalam perjalanan bangsa Indonesia khususnya di kota Makassar. Masyarakat banyak terbantu oleh kegiatankegiatan tersebut misalnya bakti sosial, advokasi, pelatihan, dan kegiatan-kegiatan lain yang sifatnya positif. Capaian tersebut adalah senada dengan pendapat Moekijat (Kamil, 2012, p.11) bahwa pelatihan bertujuan mengembangkan keahlian sehingga pekerjaan dapat diselesaikan dengan lebih cepat dan lebih efektif, mengembangkan pengetahuan sehingga pekerjaan dapat diselesaikan secara rasional, mengembangkan sikap sehingga menimbulkan kemauan untuk bekerja sama. Pendapat tersebut menandakan bahwa kader HMI memiliki keahlian dalam mengurusi persoalan kemanusiaan, memiliki pengetahuan memecahkannya, dan memiliki semangat solidaritas yang tinggi. Selain itu, di lingkungan kampus informan penelitian banyak terlibat dalam mendorong berkembanganya tradisi intelektual meskipun belum merata disetiap komisariat. Akan tetapi, wadah tersebut sedikit banyaknya memberi kesempatan bagi kader-kader baru ataupun mahasiswa yang lain mengeksplorasi ide dan gagasan yang dimilikinya. Pada konteks organisasi, informan penelitian aktif dalam setiap agenda organisasi dan telibat membantu keluarga mereka di rumah. Ratarata informan terlibat dalam kepanitiaan ataupun kepengurusan di HMI tataran komisariat, tataran koordinator komisariat, sampai pada tataran HMI cabang. Bukan hanya di HMI saja, kader juga banyak bergabung di organisasi lainnya, baik intra kampus maupun ekstra kampus.

Kondisi realitas di atas menunjukkan suatu hal yang tidak saling terbangun antara pencapaian tujuan jangka pendek dan dampak basic trainin) HMI cabang Makassar. Dalam mencapai tujuan pelatihan tersebut kader tidak digenjot pada wilayah keislaman/keagamaan sehingga memberikan dampak negatif dalam konteks keislaman. Akhirnya, keluaran yang yang diharapkan tidak mengarah kepada hasil tujuan pelatihan dasar HMI cabang Makassar. Meskipun pelatihan dasar HMI cabang Makassar konsisten dengan kebutuhan dan kebijakan organisasi, tetap saja perubahan yang tercipta tidak mampu bertahan dalam waktu yang lama.

Seorang kader banyak mengakui jika dirinya masih sering melanggar larangan Tuhan. Hal tersebut tidak terjadi secara natural, tentu disebabkan oleh proses yang berjalan sebelumnya. Keberhasilan sebuah program ditentukan oleh kualitas proses yang dilalui oleh seorang kader. Oleh karena itu, HMI cabang Makassar tidak boleh menyepelekan setiap tahapan yang dilalui oleh calon kader HMI. Hanya dengan keseriusan, program basic training akan memberikan implikasi yang benar-benar berkualitas. Pencapaian tujuan tersebut, tentu mempengaruhi kualitas dampak pelatihan, hal ini dapat dilihat dari kelemahan kader HMI cabang Makassar pada wilayah keislaman/ religiuitas.

\section{Keluaran Program Basic Training}

Keluaran program latihan dasar dapat dilihat dari kompetensi yang dimiliki. Kompetensi tersebut berupa penguasaan materi 


\section{Jurnal Pendidikan dan Pemberdayaan Masyarakat, 3 (1), Maret 2016 - 9}

Andi Hasdiansyah, Yoyon Suryono

dasar dan materi suplemen yang diberikan saat pelatihan berlangsung. Pada substansinya, penguasaan dan pemaknaan materi basic training HMI cabang Makassar secara serius tentu memiliki pengaruh dalam dinamika perubahan paradigma kader dalam hal ini informan penelitian. Demikian halnya dengan perubahan sikap yang berusaha dibangun, tentu berhubungan langsung dengan model atau pola pengakderan HMI cabang Makassar. Artinya, kualitas keluaran ditentukan oleh proses pendidikan atau pengkaderan di HMI cabang Makassar.

Setelah melakukan penyelidikan secara mendalam tentang kemampuan kader HMI atas berbagai materi pelatihan ditemukan berbagai kelemahan. Hasil wawancara dengan informan menunjukkan bahwa kader alumni basic training belum terlalu menguasai materi pelatihan secara detail. Informan mengaku hanya memahami kulit luarnya saja, dan terbukti kurang mampu mendeskripsikan materi pelatihan. Bahkan beberapa diantara informan sudah lupa materi basic training. Kondisi tersebut tercipta karena tahapan pendampingan alumni pelatihan tidak berjalan maksimal. Informan mengaku dijanji follow-up atas materi pelatihan tetapi pada kenyataannya janji tersebut tidak mampu terealisasi dengan baik. Pada wilayah ini, dapat dikatakan bahwa ada problem yang dihadapi HMI cabang Makassar yaitu keseriusan kader-kader pada tataran pengurus komisariat. Akhirnya, keraguan atau ketidakpercayaan seringkali muncul dibenak alumni pelatihan. Informan mengaku bahwa penyelenggara kegiatan kurang bertanggung jawab dan seakan-akan alumni pelatihan dilepas begitu saja. Selain itu, tidak adanya proses evaluative secara continue yang dilakukan oleh pengelola program untuk memastikan kompetensi keluaran. Senada dengan pendapat Sukardi (2014, p.9) bahwa evaluasi program digunakan sebagai perwujudan rasa tanggung jawab pengelola program pelatihan atas kepercayaan yang telah diberikan untuk mengelola program pendidikan dan pelatihan

Penguasaan materi pelatihan yang tidak optimal tentu disebabkan oleh aktivitas basic training dalam forum pengkaderan. Oleh karena itu, aktivitas pengkaderan merupakan salah satu fase terpenting yang harus dikemas baik agar bisa menghasilkan output yang berkompeten. Terbukti bahwa lulusan basic training HMI cabang Makassar secara garis besar tidak memiliki kompetensi yang baik dalam hal penguasaan materi pelatihan.

Secara umum dapat dideskripsikan bahwa tujuan pembelajaran yang dibuat oleh HMI cabang Makassar belum sepenuhnya terwujud sehingga berimplikasi pada keluaran. Pada prosesnya, proses pembelajaran dapat dikatakan alot namun, terdapat hal substansial lainnya yang tidak diperhatikan dengan baik. Hal tersebut berupa pemanfaatan sarana dan prasarana yang belum sesuai dengan waktu meskipun telah disediakan dalam kualitas yang baik, jadwal yang telah disepakati dalam kontrak belajar masih sering diluar perhitungan panitia pelaksana kegiatan. Akan tetapi, terdapat realitas lain yang mampu diwujudkan yaitu, keluaran yang diciptakan dari pelatihan dasar HMI cabang Makassar bersifat ekonomis. Secara sengaja, panitia pelaksana mengajak peserta pelatihan untuk mandiri dan belajar bertahan hidup dalam keadaan yang sulit. Pada aspek keluaran, beberapa hal yang menjadi penilaian penting dalam pelatihan dasar HMI cabang Makassar. Beberapa poin evaluasi tersebut diantaranya, HMI cabang Makassar tidak memperhatikan sarana dan prasarana pelatihan, pihak HMI cabang Makassar tidak mampu bertindak tegas atas ketidakdisiplinan pemateri mengisi waktu pelatihan.

\section{Aktivitas Program Basic Training}

Aktivitas basic training HMI cabang Makassar adalah proses pengakaderan dimana peserta pelatihan diberikan materi dasar dan materi suplemen. Lebih dari itu, terdapat banyak komponen yang melengkapi jalannya pengkaderan diantaranya metode pelatihan, materi pelatihan, suasana pelatihan, sarana dan prasarana, jadwal pelatihan, dan fasilitator.

Basic training HMI cabang Makassar pada konteks pembelajaran lebih banyak menggunakan metode ceramah, diskusi, ice breaking, dan indoktrinasi. Metode tersebut diterapkan dalam materi yang berbeda-beda 


\section{Jurnal Pendidikan dan Pemberdayaan Masyarakat, 3 (1), Maret 2016 - 10}

Andi Hasdiansyah, Yoyon Suryono

dan tidak menutup kemungkinan dalam satu materi bisa saja menggunakan keempat metode tersebut. Setiap pemateri memiliki gaya khas sendiri dalam menyampaikan materi dan yang pasti setiap materi tersebut harus benar-benar diterima oleh peserta pelatihan. Oleh karena itu, model pembongkaran konstruksi berpikir peserta pelatihan selalu hadir mewarnai proses pengkaderan di HMI cabang Makassar. Pembongkaran paradigma lama dilakukan dengan cara memberikan kontradiksi atas argumentasi yang disampaikan oleh peserta pelatihan. Pembongkaran tersebut bertujuan untuk meloloskan pengetahuan baru masuk ke dalam benak peserta pelatihan. Setelah itu, pengisian pemahaman baru dilakukan dan model yang digunakan adalah diskusi atau ceramah. Lebih lanjut, setiap materi basic training menggunakan teknik ice breaking dengan tujuan menyegarkan kembali kondisi peserta pelatihan. Materi tersebut berupa materi dasar HMI dan materi suplemen. Materi dasar itu sendiri adalah materi yang wajib ada, sedang materi suplemen adalah materi yang bisa berubah tergantung kebutuhan komisariat penyelenggara basic training.

Selain hal tersebut, suasana pelatihan merupakan salah satu hal yang harus diciptakan baik di dalam forum maupun di luar forum pelatihan. Suasana tersebut sangat berfungsi mengatasi kebosanan belajar peserta pelatihan. Suasana yang harus tercipta di dalam forum adalah kesetaraan, dan hal itu benar-benar diciptakan oleh pemateri pelatihan. Kesetaraan di dalam forum diakui oleh seluruh informan penelitian bahwa tidak ada peserta pelatihan yang merasa terdiskriminasi. Seiring dengan itu, kegairahan belajar peserta pelatihan tumbuh. Peserta aktif memberikan pertanyaan atau argumentasi rasional terhadap persoalan yang sedang dibahas dalam forum pelatihan.

Kemantapan iklim yang terbangun di atas memberikan efek pada proses pembelajaran di dalam ruangan. Akan tetapi, masih ditemukan keganjilan yaitu, tidak terbangunnya nuansa islami pada proses pengkaderan yang kadang berlangsung hingga 7 malam. Ritual keagamaan seperti mengaji bersama, shalat bersama, dan berdoa bersama sama sekali sulit ditemui dalam basic training HMI cabang Makassar. Nuansa keislaman yang muncul hanya pada persoalan menjadikan dalil Al Quran menjadi dasar argumentasi pemateri. Bukan hanya ritual keagamaan yang sulit ditemui, taman bacaan atau perpustakaan dalam arena pelatihan sama sekali tidak tersedia, karena itulah peserta diwajibkan membawa buku ke lokasi pengkaderan.

Sarana dan prasarana termasuk perpustakaan yang tidak tersedia menyebabkan peserta pelatihan tidak memiliki ruang konfirmatif atau ruang evaluasi atas pengetahuan baru yang telah didapatkan. Sarana dan prasarana yang telah disediakan tidak mampu termanfaatkan dengan baik sesuai dengan waktu yang telah disediakan. Meski demikian, ketidaklengkapan sarana dan prasarana yang digunakan dalam basic training HMI cabang Makassar, antusiasme peserta pelatihan tetap terjaga. Oleh karena itu, kreativitas penyelenggara dalam memanfaatkan sarana dan prasarana yang telah tersedia sangat dibutuhkan. Hasil wawancara dan pengamatan yang dilakukan menunjukkan bahwa seluruh sarana dan prasarana yang ada digunakan sesuai dengan kebutuhan peserta pelatihan namun kadang ada keterlambatan distribusi atau dengan kata lain pemanfaatannya tidak tepat waktu.

Sedangkan pada konteks jadwal dan anggaran pelatihan, masih ditemukan ketimpangan. Salah satunya adalah ketidakdisiplinan pemateri terhadap jadwal yang telah ditentukan oleh penyelenggara pelatihan. Akibatnya, materi yang disampaikan harus dipersingkat agar alokasi waktu materi yang lain tidak terganggu. Berawal dari kondisi tersebut materi yang diturunkan tidak lengkap karena persoalan jadwal yang tidak sesuai. Tentunya kejadian pada tahapan ini berkorelasi dengan kompetensi lepasan basic training. Menurut informasi yang didapatkan di lapangan, kader dijanji akan diberikan lagi materi-materi yang tidak lengkap pada proses follow up. Tetapi hasilnya nihil, agenda tersebut tidak berjalan maksimal sesuai dengan harapan alumni pelatihan. Sedangkan untuk anggaran pelatihan, dinilai mencukupi kebutuhan peserta selama pelatihan berlangsung, adapun berbagai kekurangan secara cepat dilengkapi oleh penyelenggara 
pelatihan. Pada akhirnya keluaran yang dihasilkan sangat ekonomis.

Komponen lain yang terdapat dalam aktivitas pelatihan adalah keberadaan fasilitator. Kemampuan seorang fasilitator adalah salah satu penentu kompetensi pelatihan. Fasilitator atau pemateri adalah orang yang telah lulus persyaratan HMI cabang Makassar. Pihak pengelola latihan dan ketua umum HMI cabang Makassar memberikan keterangan terkait kualifikasi pemateri dalam basic training bahwa semua fasilitator adalah lulusan intermediate training. Selain itu, fasilitator basic training HMI cabang Makassar telah mengikuti program senior course, TOT, dan pernah menjadi instruktur tetap dalam basic training sebanyak 25 kali pertemuan. Adapun persyaratan lain adalah mendapat pengakuan dari pemateri sebelumnya tentang penguasaan materi yang didalaminya. Pada aspek ini, poin penting yang bisa dijadikan penilaian adalah tidak tersedianya sarana dan prasaran utama seperti ruang baca dan perpustakaan. Oleh karena itu, hal ini harus diperbaiki agar bisa menunjang pelatihan dasar selanjutnya.

\section{Masukan Program Basic Training}

Masukan pelatihan adalah elemen yang akan mengisi dan menunjang jalannya pengkaderan. Pada basic training HMI cabang Makassar, komponen masukan tersebut terdiri atas sumber pendanaan, peserta, dan sarana dan prasarana. Berawal dari pendanaan basic training HMI cabang Makassar. Pada konteks ini, biaya pelatihan didapatkan dari sumbangan atau donatur yang berasal dari kalangan senior HMI, selain itu sumbangan tambahan diperoleh dari sumbangan peserta pelatihan. Sumbangan yang berasal dari peserta pelatihan tersebut didapatkan pada saat materi konstitusi berlangsung bukan pada saat pendaftaran. Proses tersebut sangat menyita perhatian peneliti, pemateri memiliki teknik tersendiri dalam mempengaruhi peserta pelatihan dan pada akhirnya peserta pelatihan dapat memberikan sumbangan tersebut secara tulus. Adapun jumlah yang dimintai adalah tergantung dari kebutuhan penyelenggara pelatihan. Hasil wawancara dan pengamatan secara tidak langsung di lapangan membuktikan bahwa biaya atau anggaran pelatihan dasar HMI cabang Makassar mencukupi kebutuhan peserta pelatihan

Sedangkan untuk peserta pelatihan sendiri berasal dari berbagai kampus yang berada dalam naungan HMI cabang Makassar. Peserta pelatihan khususnya yang berasal dari Universitas Negeri Makassar adalah mahasiswa berstatus aktif dibuktikan dengan kartu mahasiswa atau bukti pembayaran Sumbangan Pembangunan Pendidikan (SPP), mampu baca Al Quran, mengetahui tata cara shalat 5 waktu, dan menyatakan bersedia mengikuti seluruh rangkaian basic training HMI cabang Makassar. Berbagai persyaratan di atas tidak sepenuhnya diujikan kepada calon peserta pelatihan pada saat mendaftar. Peserta pelatihan dalam hal ini informan penelitian mengakui bahwa proses pendaftaran hanya diwarnai dengan pengembalian formulir dan pengakuan atas kesanggupan calon peserta mengikuti seluruh rangkaian basic training. Selain daripada itu, persyaratan lain tidak diminta atau diujikan sehingga berimbas pada keseriusan peserta pelatihan menjalani proses pengkaderan. Pada fase ini, totalitas penyelenggara pelatihan kurang maksimal padahal, kelengkapan dan kemampuan peserta sebelum mengikuti pelatihan sangat penting menjadi acuan dalam menilai perkembangan peserta pelatihan. Ketika hal tersebut dilakukan maka akan dengan mudah memantapkan dan memetakan tahapan pengkaderan selanjutnya. Sayangnya, di HMI cabang Makassar sulit ditemui hal tersebut yaitu mengacu pada pedoman dasar pengkaderan HMI.

Selain daripada hal di atas, komponen masukan berupa ketersediaan sarana dan prasana menjadi penting dalam menunjang proses pengkaderan HMI cabang Makassar. Pada konteks ini, penyelenggara kegiatan harus berpikir dan mampu menyiapkan penunjang pelatihan selama 3 sampai 4 hari ke depan. Artinya, sebelum kegiatan berlangsung sarana dan prasarana sudah harus tersedia dan mencukupi kebutuhan pelatihan selama hari yang dimaksud. Sarana yang dimaksud misalnya logistik, alat tulis menulis, dan obat-obatan. Untuk HMI cabang Makassar sendiri telah menyediakan sarana dan prasarana tersebut sebelum kegiatan 
berlangsung. Akan tetapi, masih sering menemui kesulitan dalam hal pendanaan sehingga berefek pada penyediaan logistik dan perlengkapan lainnya. Temuan dilapangan menunjukkan bahwa logistik kadang datang terlambat sehingga peserta pelatihan harus menunggu beberapa waktu. Dampak dari masalah itu adalah menyita alokasi waktu materi yang lain. Begitupun dengan alat tulis menulis, penyelenggara pelatihan tidak menyediakan untuk semua peserta pelatihan. Perlengkapan tersebut dibawa sendiri oleh peserta dan apabila diantara peserta ada yang tidak membawa makan kewajiban penyelenggara kegiatan menyediakan. Boleh dikatakan sifatnya insidental. Perlengkapan lain yang bersifat insidental adalah obatobatan, disediakan apabila dibutuhkan. Pada aspek masukan ini, dapat dinilai bahwa pada proses rekrutmen anggota/peserta pelatihan sangat jarang ditemui penyelenggara kegiatan melakukan tes kemampuan pada bidang keagamaan misalnya, mengaji, shalat, dll.

\section{Rekomendasi Pengembangan Model Basic Training HMI cabang Makassar}

Temuan penelitian yang telah disajikan menghasilkan sebuah penilaian objektif atas penyelenggaran basic training HMI cabang Makassar. Temuan tersebut didapatkan dari hasil evaluasi yang dilakukan dengan menggunakan pendekatan logic. Pendekatan tersebut dimulai dari dampak pelatihan baik secara individual maupun secara organisasional. Dampak yang dihasilkan tentunya memiliki hubungan kausalitas dengan seberapa maksimal tujuan dari pelatihan tersebut tercapai. Begitupun seterusnya, ketercapaian tujuan tidak lepas dari kompetensi keluaran. Kompetensi keluaran tersebut tidak akan diraih tanpa proses pembelajaran yang berkualitas. Tentu, untuk mendorong kualitas pembelajaran yang berkualitas harus diawali dengan masukan yang baik pula seperti, keseriusan calon peserta, kompetensi fasilitator, dan ketersediaan sarana dan prasarana yang memadai.

Melalui pendekatan logic, berbagai kelemahan basic training HMI cabang Makassar yang sifatnya sistematik bisa diungkap secara objektif. Kelemahan tersebut berada pada dampak pelatihan yaitu tidak terbangunnya nilai-nilai keislaman di dalam diri masing-masing kader sehingga, dalam menjalani kehidupan sehari-hari baik berkarya ataupun aktivitas kehidupan lainnya tidak selamanya berpedoman pada islam. Kelemahan tersebut berasal dari pola pengkaderan dasar HMI cabang Makassar. Terlihat ketidakseriusan penyelenggara pelatihan mendorong tercapainya tujuan basic training dan pemaknaan materi-materi dasar keislaman yang kurang berhasil. Realitas tersebut tentu disebabkan oleh pembinaan yang tidak berjalan maksimal.

Pembinaan alumni basic training HMI cabang Makassar merupakan tanggungjawab komisariat penyelenggara pelatihan. Hal itu dilakukan agar alumni pelatihan mampu mendalami secara khidmat materi-materi dasar keislaman tersebut. Oleh karena itu, di dalam proses pengkaderan HMI cabang Makassar harus memantapkan kajian keislaman kepada peserta pelatihan agar keluaran basic training memiliki kemampuan mengaplikasikan nilai-nilai islam dalam kehidupan sehari-harinya. Selain proses yang wajib dimantapkan tentu HMI cabang Makassar harus meminimalisir kelemahan administrasi pada saat pendaftaran. Pada konteks tersebut, peneliti menemukan beberapa kekurangan misalnya, tidak adanya uji kemampuan peserta pelatihan di bidang keagamaan/keislaman sehingga penyelenggara pelatihan tidak mengetahui kemampuan calon peserta pelatihan.

Kelemahan yang hadir dalam penyelenggaraan basic training HMI cabang Makassar harus diminimalisir dengan cara memperbaiki pengelolaan pelatihan khususnya pada bidang administrasi. Sebaiknya penyelenggara kegiatan harus memperketat proses pendaftaran dengan melakukan uji kemampuan calon peserta pelatihan di bidang keislaman. Sekiranya HMI mengidentifikasi diri sebagai organisasi khalifah, maka sebuah kewajiban yang tidak boleh ditunda lagi untuk memantapkan poros keislaman di tubuh HMI cabang Makassar. Hanya dengan mengembangkan aspek-aspek tersebut, sikap dan pola pikir yang mencerminkan khalifah Allah SWT di muka bumi ini akan terwujud. Pada akhirnya, kualitas sumber 
Jurnal Pendidikan dan Pemberdayaan Masyarakat, 3 (1), Maret 2016 - 13

Andi Hasdiansyah, Yoyon Suryono

daya pemuda khususnya di makassar bermanfaat bagi kehidupan bangsa dan negara.

Dari pendekatan logic tersebut HMI cabang Makassar belum menjalankan operasionalisasi program dengan baik. Seperti yang diungkapkan oleh Suryono (2007, p.47) bahwa jika input disediakan dengan dalam jumlah dan waktu yang tepat maka akan menghasilkan sebuah keluaran yang baik, keluaran yang dihasilkan tentunya akan memberikan dampak dan manfaat yang baik pula, dan jika tujuan tersebut tercapai maka secara otomatis tujuan umum atau dalam hal ini 5 kualitas insan cita HMI cabang Makassar akan ikut tercapai. Akan tetapi, penyelenggaraan basic training HMI cabang Makassar belum berjalan secara logic sesuai dengan harapan perspektif tersebut.

\section{SIMPULAN DAN SARAN}

\section{Simpulan}

Dampak program basic training telah sesuai harapan konstitusi HMI. Perubahan yang dihasilkan dari basic training tersebut adalah terbangunnya kesadaran akademik, terbinanya insan yang selalu menciptakan perbaikan atas setiap pemasalahan yang terjadi di lingkungannya, terbinanya kesadaran pengabdian dan bertanggungjawab atas terwujudnya masyarakat adil makmur yang diridhoi Allah SWT. Terdapat pula perubahan yang tidak dinginkan yaitu kader belum mampu sepenuhnya menjalankan perintahNya dan menjauhi laranganNya. Beberapa kader masih sering meninggalkan shalat 5 waktu, melakukan kegiatan-kegiatan yang tidak bermanfaat, dan belum mampu mengamalkan ilmunya dengan berpedoman pada Al Quran dan Hadist.

Tujuan pelatihan dasar HMI cabang Makassar telah tercapai meskipun belum sempurna tetapi telah mengarah kepada hasil yang diinginkan. Selain itu, tujuan pada dasarnya konsisten dengan kebutuhan dan kebijakan organisasi akan tetapi, ketercapaian tujuan tidak mampu bertahan lama.

Keluaran pelatihan dasar HMI cabang Makassar pada konteks ketercapaian tujuan pembelajaran sebenarnya telah tercapai dengan baik dan mengarah kepada hasil yang diinginkan. Akan tetapi, apa yang dicapai tersebut tidak mampu dipertahankan dengan baik sehingga lambat laun dari tahun 2010/2011 sampai tahun 2015 kompetensi yang sebelumnya dimiliki kader melemah. Kader kurang mampu mendeskripsikan secara menyeluruh setiap materi pelatihan dasar terkhusus untuk materi-materi terkait keislaman. Sedangkan pada konteks sarana dan prasarana basic training HMI cabang Makassar tersedia sesuai dengan kebutuhan pelatihan. Keluaran basic training juga mampu dihasilkan secara ekonomis.

Aktivitas pelatihan memiliki pengaruh besar terhadap keluaran pelatihan. Pada tahapan ini proses pembelajaran sudah cukup baik, fasilitator mampu mendorong animo belajar peserta pelatihan. Sarana dan prasana yang disediakan dalam kondisi yang baik dan ketersediaannya sangat ekonomis. Akan tetapi, kesuksesan yang diraih pada aspek pembelajaran berakhir pada forum pengkaderan saja. Pola pembinaan lanjutan tidak mampu dijalankan secara maksimal oleh penyelenggara kegiatan sehingga animo belajar tersebut tidak terjaga dengan baik. Selain itu, kebiasaan tidak disiplin menjadikan kualitas pengkaderan pada satu sisi berpengaruh terhadap keluaran pelatihan.

Masukan basic training HMI cabang Makassar pada konteks biaya pelatihan sudah mencukupi kebutuhan dan penyelenggara pelatihan sedikit banyaknya telah menyiapkan sarana dan prasarana sebelum pelatihan berlangsung. Namun proses perekrutan belum sepenuhnya berpedoman pada pedoman pengkaderan HMI. Penyelenggara pelatihan tidak mampu menjalankan prosedur perekrutan anggota secara teratur sehingga menimbulkan kesan "bebas". Setiap mahasiswa yang ingin masuk menjadi peserta pelatihan dasar HMI cabang Makassar tidak melalui tes tertentu misalnya tes kemampuan baca Al Quran, mengucapkan dua kalimat syahadat, dan praktik shalat. Lebih sederhananya lagi, proses perekrutan anggota HMI cabang Makassar tidak bernuansa islam.

Hambatan program pelatihan dasar HMI cabang Makassar yang kadang digelisahkan oleh para penyelenggara kegiatan adalah persoalan pendanaan. Selain itu, kurangnya kedisiplinan pemateri dan peserta 
Jurnal Pendidikan dan Pemberdayaan Masyarakat, 3 (1), Maret 2016 - 14

Andi Hasdiansyah, Yoyon Suryono

pelatihan sehingga kadang membuat jadwal yang telah dibuat berubah.

Hasil evaluasi ini merekomendasikan beberapa hal terkait pengembangan basic training HMI cabang Makassar diantaranya memantapkan kajian keislaman pada peserta pelatihan, meminimalisir kelemahan administrasi, dan memperketat proses perekrutan anggota, serta melakukan uji kemampuan keagaamaan terhadap calon peserta pelatihan agar penyelenggara pelatihan memiliki peta atau petunjuk aspek-aspek apa saja yang harus dibangun dalam diri peserta di dalam pelatihan yang akan dilaksanakan.

\section{Saran}

Kepada badan pengelola latihan: sebaiknya memantau proses pendaftaran dan perekrutan peserta basic training HMI cabang Makassar dan mewajibkan dan jika perlu memberi sanksi apabila pihak penyelenggara basic training tidak mematuhi pedoman pengkaderan yang telah disediakan.

Kepada penyelenggara: pelatihan sebaiknya menunjukkan sikap keseriusan dalam proses pembinaan alumni basic training HMI cabang Makassar. Kepada pengurus HMI cabang Makassar pengelola latihan, fasilitator atau pemateri: sebaiknya saling bersinergi menunjukkan sikap keseriusan terhadap perjuangan yang benar-benar bernafaskan islam. Sebaiknya setiap materi basic training terintegrasi dengan konsep-konsep Islam yang sesuai dengan Al-Quran dan Sunnah Nabi.

Pengurus HMI cabang Makassar sebaiknya mengembangkan model pelatihan yang telah ada dengan mendorong semangat islam di dalam setiap tahapan pengkaderan.

\section{DAFTAR PUSTAKA}

Djuwariah, (2008). Peningkatan kualitas sumber daya manusia melalui pendidikan islam. [versi elektronik]. El-Tarbawi, No. 1. Vol. I. Diambil pada tanggal 18 Agustus 2014.

Federation International. (2002). Handbook for monitoring and evaluation. Switzerland: International Federation of Red Cross and Red Crescent Societies.
Goldstein, I. L \& Ford, J. K. (2002). Training in organization. Canada: Vicky Knight.

Jorjani, H. (1994). The holistic perspective in the evaluation of public programs: a conceptual framework [Versi Elektronik]. The Canadian Journal of Program Evaluation. Vol. 9. No. 2 ISSN 0834-1516.

Kamil, M. (2012). Model pendidikan dan pelatihan (konsep dan aplikasi). Bandung: Alfabeta.

Bower, E.P., Li, Y., Kiely, M.K., Brittian, A., Lerner, J.V., \& Lerner, R.M. (2010). The five cs model of positive youth development: A longitudinal analysis of confirmatory factor structure and measurement invariance. Journal Youth Adolescence 39 (7), pp.720-735. Retrived from http://link.springer.com/article/10.10 07/s10964-010-9530-9

Mappiare, A. (1982). Psikologi remaja. Surabaya: Usaha Nasional.

Marzuki, S. (2012). Pendidikan nonformal (dimensi dalam keaksaraan, pelatihan, dan andragogi). Bandung: PT Remaja Rosdakarya.

Moerdiyanto. (2011). Pembangunan kepemimpinan pemuda berwawasan kebangsaan dan cinta tanah air. Diambil pada tanggal 26 Agustus 2014, dari http://staff.uny.ac.id/sites/default/fil es/pengabdian/drs-moerdiyantompd/artikel-pengembkepemimpinan-pemuda-moer.pdf.

Nuralam, A \& Sahide, A. (2011). HMI (pemikiran dan gerakan intelektual). Yogyakarta: The Phinisi Press Yogyakarta.

Robbins, S. P. (2008). Perilaku organisasi. Terjemahan. Jakarta: PT Indeks.

Sitiatava, R. P. (2013). Desain evaluasi belajar berbasis kinerja. Yogyakarta: DIVA Press.

Sudjana, D. (2008). Evaluasi program pendidikan luar sekolah (untuk pendidikan dan pengembangan sumber daya 
Jurnal Pendidikan dan Pemberdayaan Masyarakat, 3 (1), Maret 2016 - 15

Andi Hasdiansyah, Yoyon Suryono

manusia). Bandung: PT Remaja Rodakarya.

Sukardi. (2014). Evaluasi program pendidikan dan kepelatihan. Jakarta: Bumi Aksara.

Suprijanto. (2008). Pendidikan orang dewasa (dari teori hingga aplikasi. Jakarta: PT Bumi Aksara.

Suryono, Y. (2007). Pengembangan sumber daya manusia. Yogyakarta: Gama Media

Syam, N. (2010). Jejak reformasi dalam lintasan sosio-historis. Diambil pada tanggal 27 Agustus 2014, dari http://eprints.uinsby.ac.id/35/1/aman demen/dalam/lintasan/sejarah.pdf
Tristanti, T., \& Suryono, Y. (2014). Evaluasi program kecakapan hidup bagi warga binaan di lembaga pemasyarakatan anak kelas IIA Kutoarjo. Jurnal Pendidikan dan Pemberdayaan Masyarakat, 1(1), 113 - 123. Retrieved from http://journal.uny.ac.id/index.p hp/jppm/article/view/2361

Wijaya, D.N. (2013). Mentalitas pemuda pada masa pergerakan dan masa reformasi di Indonesia: Dari berani berpengetahuan hingga takut berpengetahuan. [versi elektronik]. Jurnal Kajian Sejarah \& Pendidikan Sejarah No. 1. Vol. 1. Diambil pada tanggal 18 Agustus 2014. 